\title{
A Study of Determinants of Service Quality and Its Role in Customer Satisfaction: A Case of Selected Hotels in Sulaimaniyah, Kurdistan Region of Iraq
}

\author{
Dr. Mamta Singh \\ Lebanese French University, Kurdistan Region of Iraq \\ E-mail: mamtasingh609@gmail.com \\ Mr. Devendra Kumar \\ Lebanese French University, Kurdistan region of Iraq \\ E-mail: devendrabajpaieco@gmail.com
}

Received: February 16, 2020

Accepted: March 12, 2020 Published: March 29, 2020

doi:10.5296/ber.v10i2.16472

URL: https://doi.org/10.5296/ber.v10i2.16472

\begin{abstract}
Purpose of the study: Hospitality and tourism is a promising sector for growth of the Economy in Kurdistan region of Iraq. Every year a massive number of tourists visit the region during Nawroz and Eid -ul-Adha festival seasons. The region is fairly modern and possesses several tourist destinations including site seeing, religious tourism and historical tourism etc. Kurdistan Regional Statistics Office published a report on region's economy that consists of number of foreign individuals, who visited Kurdistan region categorized into Arab and Non-Arab visitors category provides a clear picture that the region is not only an attraction for holiday but also for other type of tourism. Therefore we wish to learn customers opinion about satisfaction from service quality of the selected hotels. The study will be used to share key information with the hotel in Sulaimaniyah city.
\end{abstract}

Methodology: To understand the determinants of service quality that is most shot for by the individuals we have conducted a survey of selected five star hotels in Sulamaniyah. The sample size for this study was a small sample which was 50 respondents. We used purposive sampling. For data analysis we used SPSS software package for social sciences.

Main Findings: We observed from the majority responses that Room service, delivery time, behavior of hotel staff, a nice welcome on arrival, variety of food and beverage are some of 
the important parameters on which customers decide to rate a hotel. The customers do not have much interest in modern furniture facilities as per this study result.

Application of the study: In the nutshell hospitality and tourism sector has huge potential for job creation given the fact the region has well-educated and well groomed young population ready to be employed in the region's growing tourism industry, this research will help the hotels to provide better services to satisfy the customer.

Keywords: Service quality, Hotel Industry, Tourism, Customer satisfaction, Sulaimaniyah

\section{Introduction}

\subsection{Background of the Study}

The tourism committee of Kurdistan planned to spend around 100 billion Dinars on various tourist projects back in 2014 and many projects are already in progress. As per a report of world bank "The Kurdistan region of Iraq (Henceforth KRI) is well located next to important potential tourism markets: Turkey, Iran, and other regions in Iraq. It can be reached by land or by air, with two international airports in Erbil and Sulaimaniyah and 26 airlines flying to/from KRI. Its main assets are its unspoiled mountain scenery and ancient archeological sites. Its cultural heritage is important, ranging from music to arts and crafts, clothing, textiles, rugs, etc. The religious tourism sector has also developed; attracting a number of tourists from around the world (the Ministry of Endowment and Religious Affairs estimated at 1 million the number of tourists who visited Islamic, Christian, Yezidi and Kakai sites at the tourism peak time). The region also counts facilities for ski and hiking”. Erbil's Citadel is one of the four sites on UNESCHO's world heritage site that is considered safe for tourists. As per the report the potential of this sector is largely untapped due to ignorance and infrastructural limitation. http://bot.gov.krd/about-kurdistan/tourism accessed on 20th January 2020

The competition between the hotel industries have led to improvement of better quality and better service, in addition the improved quality of service among the hotels will end up having more satisfied customers that brings customer loyalty to the hotel. The hotel industry largely depends upon the tourist destinations. In developing countries high class hotels are mainly focusing on the customer's income, occupation, and family life cycle in other words their demographic factors. Therefore, the hotel focuses on matching the needs and wants of their customers to give the ultimate customer service. For instance, a wealthy person might travel a lot and they are mostly staying in a one hotel franchise because they might feel comfortable or satisfied with their hospitality.

In the Kurdistan region, Sulamaniyah province is experiencing a normal season for Business. When looking at the recent activities in the city we can highlight that Sulaymaniyah economic structure is transforming in terms of more educated youth, diversity which makes it more suitable to engage in service activities. The service sector includes the tourism industry which is also one of the promising industries as far as job creation and economic contribution is concerned. 
Service quality is very important in the hotel industry, particularly in the hotels that have high value in customer's mind. The hotel invests heavily for the training of its employees, the products and services that they provide so that they can maintain a competitive advantage. The factors that count the most for better service quality are many but for instance, Employees are one of the main inputs of the hotel's hospitality that has direct contact with the customers. Therefore, hotels invest heavily in recruiting and selecting the employees who make friendly contact with the customers. Another factor that affecting the quality of services is the machines, which includes the advancement of use of the technology and how useful this is for the hotel industry which is boosting the productivity and ensuring the superiority. The third is relaxing activities. In order to remain on the top, the hotel tries to outperform as compared to their competition. Another important factor is the environment of the hotel, in the area of Sulaymaniyah, which can be a great impact on the quality service that a customer receives from the hotel. This is in terms of characteristics as: room size, color, furniture's, etc. These features create certain effects in buyers mind about the quality of service at the hotel. Additional factor is the management that affects the overall industry, which is the management that sets all the policies related to both service and quality. Motivation factor is the element that keeps the employers driven to perform at their best abilities, this can be given through rewards and recognition of their performance. On the other hand is the hotel price, which is what the customers pay when checking into a specific hotel that they have chosen, the price affects the quality and service that the customers receive whether it is high or low and the service is good or bad. The main factors mentioned above are how these impact the quality of service that they provides for their customers and is applicable for most if not every hotels in Sulaymaniyah.

\subsubsection{A Brief Description of Hotels in Sulaimaniyah City}

This research is based on three different hotels in Kurdistan, Sulaymaniyah region. The hotels include Ramada, High crest and Grand Millennium hotel, undertaking a research on these hotels gives an insight on their quality of service and how they operate within the hotel besides handling customers. Ramada hotel was first established in 2014 which is located within the heart of Sulaymaniyah, it is located near Bazar (Most vibrant Shooping area in the city) and many other cultural areas which gives an advantage to tourists, who visit Sulaymaniyah city. Ramada hotel is one of the finest hotels in the city with a five star rating, many tourists choose Ramada hotel because of its high standards and mainly because it's perfect location. Additionally High Crest Hotel is another five star hotel that is also located within the city of Sulaymaniyah, this hotel is positioned near the Sulaymaniyah international airport. Furthermore, and right across High Crest hotel is one of the largest malls "Majidi Mall". High Crest hotel tries to satisfy their customers in every possible way, with a low price range through a high quality service. On the other hand, the city has other hotels of similar ratings and standards like Ramada and High Crest, for instance Grand Millennium. The hotel is committed to give comfort and luxury to their customers. They have relatively a good name and have positioned their self in the consumers mind as a luxury hotel in town. 
1.2 Research Question

- What are the determinants of service quality for a customer while rating a hotel in Kurdistan, Sulaymaniyah city?

- What are the key areas where hotels in Sulaimaniyah could improve their service quality?

\subsection{Motivation of the Study}

The main goal is to study each of these hotels service quality and to be able to understand how satisfied and dissatisfied customers are with the hotels in Sulaymaniyah city; the outcome will provide readers with every detail of all three selected hotels. Service quality simply means the assessment of how well the service is delivered to their customers, the hotel industry use this method to operate and serve their customers and to get a feedback in order to improve their credibility and to quickly identify every dissatisfactory behavior or object. The findings of this study will attempt to get the information to gain a benefit for the hotel businesses as a whole, considering that the hotel industry acts as an important industry for today's business and economic activities. In order to sustain and grow further as a country there is a need for a further investigation on why the tourist and hospitality needs to be further developed as per International standards? As a matter of fact the hotels make huge creation of jobs for the residents in the city. In addition if you have a successful hotel industry this will attract consumers from around the world since KRI is a prominent tourist destination for neighboring countries. It is also noteworthy to understand the competitors critically in order to predict their potential future strategies and stay relevant.

\subsection{Aim and Objectives of the Study}

The purpose of this study is to give a background of hospitality business service quality status, also an understanding on hospitality service within Kurdistan region. This paper mainly focus on three high class hotels in Sulaymaniyah city including Grand Millennium hotel, High Crest hotel and Ramada hotel. Studying these three hotels in Sulaymaniyah will help with accomplishing the objectives of this research, which will include comparing the service quality between these three hotels. The main objective of this paper is to identify the main differences between these hotels, their service, offers, strategies to attract customers, and their hospitality towards customers. How customers feel about hotel hospitality is an important factor for the hotel, which leads to a competitive field for these three high class hotels in Sulaymaniyah city. Competition sets an objective for the hotels to always increase their qualities and services, and which leads them to increasing their service quality in the most possible way in order to stay at the top of the hotel industry.

\section{Literature Review}

\subsection{Introduction}

This chapter demonstrates the literature review on hotel industries including a few specific countries. It will also explain the service quality of these hotel industries in different countries, giving background on these hotels that have been selected for this research. The 
hospitality industry has expanded over the years; tourists always search for the most suitable hotel that is near to the places they want to visit, as well as a hotel with a high-quality service that they will feel satisfied when staying in this hotel. Customers always look forward to a hotel with great service, because currently hotels are not just buildings with rooms that people can rent, it has become a huge industry and can also have a heavy impact on economic factors. Hotels have developed hospitality that always looks for new ways to serve their visitors.

\subsection{Theoretical Review}

Various Theoretical researches have been done on service quality of hotel industries worldwide. Approximately $70 \%$ of the world GDP is coming from the service sector, among this, the hotel industry has become one of the dominant of the services. In recent years, it became noticeable that quality becomes the main priority. And in order to make sure to keep the quality as per customer expectation we need to learn customer expectation and feedback. https://data.worldbank.org/indicator/NV.SRV.TOTL.ZS accessed on 20th January 2020.

\subsection{Quality Impact on Market Theory}

According to Grove S.J and R.P Fisk (1997) benefits from a high quality service will result in a greater competitive positioning in the market. They carried out a research that shows results for a sample of 2600 companies in the US, within the period of 1987 and 2002. In the research a direct link was found between the level of quality of goods and services related to their financial performances. As a result, it was detected that all indicators of the success of a company, such as market share, return on investments, property turnover coefficient confirms a greater role in relation with better quality of goods and services. According to past studies it has been stated that the efficiency of the whole system is manageable only if we observe, monitor and analyze what the customers want, in other words, the demand. The term quality has more meaning and has a more detailed explanation. It is a buildup of multiple elements and criteria. In order to keep the quality at the top, it is a need to have in mind all the elements and criteria of quality, as in fact, they are equally important. In order to sustain the quality and obtain it as much as possible, it is important to not miss even one of the elements. On the other hand, product or service has to ensure the satisfaction of one of the defined element of quality. In the time of highly increasing competition, market globalization and the growing improvement of modern technology sustaining service quality is becoming even more challenging.

The problem in service quality measurement comes from a lack of clear and measurable parameters for the purpose to determine customer satisfaction. Unlike measuring a product quality, the quality of a product is easier to detect, for the reason that a product is manageable to indicate its durability, number of defective products etcetera. This makes it easy to determine what level of quality a product has contrast to measuring service quality. In our research we tried to understand from the given variables by KRG government how customers rate the selected hotels. 


\subsection{Customer Satisfaction Review}

Oliver (2000) defines customer satisfaction as: "Satisfaction is the consumer's fulfillment response". It is a judgment that a product or service feature or the product of service itself, provided a pleasurable level of consumption-related fulfillment, including levels of under- or over-fulfillment. Analyzing further companies, the more the better it is to compare data and obtain a realistic image. In this way, it is possible to position your company in the market and be comparable regarding quality. In order to rationalize the system approach towards a standard of quality, related to the current researches, asserting hotel service quality was advanced into specific dimensions. Mainly three dimensions are being expressed. Which consist of interaction quality, which is the communication between a consumer and an employee is being held? Secondly the look, greenery and aesthetics.

Brady and Cronin (2001), additionally defined the sub categories of service quality. Primarily for the communication part, which is followed by expertise and problem-solving, atmosphere, room quality, facility, design and location.

Bowen \& Swartz (1992) has explained the industry of tourism and hotel business is free from obligations that concerns with service quality it is important to compare and differentiate between hotel's service qualities with its competitors; in a highly competitive hotel industry it is important to recognize the different service qualities between competitor hotels and high quality hotels. Managers should understand customer's needs and wants by offering them high quality service in order to satisfy their customers and achieve the hotel's goal. The key to find out the hotels quality service is fulfilling the expectation of customer's. They find out by distributing surveys and getting feedback from them.

\subsection{Findings in KRG on Hotel Industry and Tourism}

Mira (2015) emphasized finding the aim to search on how the capital of city in Kurdistan region, Erbil has become a destination for tourists and travelers. The destination has in recent years accomplished most attractive destination in the region. This was a step forward in the development of the Kurdistan's General Board of Tourism. The goal is to manage the business in a way to ensure customer satisfaction in all parameters. This tactic leads to a growth of Value, flexibility, effectiveness, and competitiveness of the industry as a whole.

\subsection{Hypothesis}

In Kurdistan, Sulaymaniyah city the service quality of hospitality industry has been paid little attention, than it needed considering the fact that it possesses huge potential. There are many hotels in the city and very few have received five star rating. Both Sulaimaniyah and Erbil host millions of tourist every year during the holiday season in the Middle East and also during Nawroz festivity. Given the tough guidelines for the government we believe customers are satisfied with the hotel services. 


\section{Methodology}

\subsection{Introduction}

The methodology of this research is based on the service quality maintenance survey through questionnaires. Survey is carried out by closed ended questionnaire. Questionnaire is delivered face to face. Target audiences were consumers from selected hotels in Sulaymaniyah. Questionnaires were delivered to 50 responders, and 30 of them returned the fully filled questionnaires. This research includes both primary and secondary data.

\subsection{Research Approach}

We followed the mixed methodology, where we used both quantitative and qualitative research. As the data was collected using the closed ended questionnaires, however while interpreting the results we were careful that the essence of the survey should not loose. The reason was to identify the issues in service quality maintenance by the hotels.

The approach of researcher was deductive, where researchers analyzed their findings on outcomes of literature review and confirmed with the result of their survey. In this process researchers disclose and describe the relationship between good quality of service and loyalty of the customers and their effects on the overall perception about the hotel by consumers. In this section we analyzed the influence of various service quality measures on customer satisfaction. These inquiries led towards understanding the best practice influence on organizational values on the performance, relationship, and effectiveness of consumer behavior and brand image. The particular focus was oriented towards brand image and consumer perception.

\subsection{Justification of Method}

According to researchers this is the best approach to achieve maximum satisfaction of outcomes because survey through questionnaires will cover the larger population than interview. It is also quick and more reliable. It is to be noted that researchers have some limitations of time as this project is part of their Undergraduate Degree and it need to complete within specified time limits. Another important thing is limitations of financial resources.

According to Saunders et al (2009) the purpose of reading of various literatures will depend upon the approach of researcher which they are intending for their research. In this research we analyzed different literatures to identify research questions and used the data to test them. This approach is known as deductive. Another approach is known as inductive approach, where researchers have to develop their theory on behalf of their collected data. Researchers believe that inductive approach requires in depth study and it needs more time to accomplish goal. It is very difficult to take interview of related person and even if researcher can arrange, and it cannot be validated and reliable due to certain limitations. Furthermore, it is expensive and researchers are not able to bear such load. Therefore we have decided deductive approach as it is easy, quick as well as less expensive. 


\subsection{Research Philosophy and Strategy}

There are four different types of philosophy mentioned in research opinion by Saunders et al 2008 (Saunders et al, 2009: 108). These are positivism, realism, interpretivist and pragmatism. Research philosophy is imperative to research strategy. However research and philosophy seems to be opposite even they co-relate each other. Research means re- investigation, while philosophy is wisdom of researcher. Therefore research philosophy is more close to the intelligence of researcher. Researcher can see the outcome by his intelligence. The branch of philosophy positivism is related to natural science. Here researcher will have to work with social reality and it like materialism investigated by physical and natural science (Remenyi et al. 1998:32 cited Saunders et al. 2009:113). While realism is related to scientific inquiry, the essence of reality is what we feel the truth. This philosophy is existed to realize the truth for objective. It means the reality is independent to the mind. There are two different types of realism, direct and critical (Saunders et al. 2009:114,115). Interpretive is for world of business and management. It is argued that business world is complex therefore by interpretivist researcher can identify the complexity of business world and management similar to physical science. According to this it is necessary to understand the role of researcher as social actor being a human. Forth philosophy is pragmatism, which leads to researcher to explore his philosophy by research. This term is generally used in social science. It is used to examine the social phenomena and exploration. Researchers have selected positivism as their philosophical approach because researchers believe that this project is to identify the social behavior of customers and they needs to describe and want to present this as physical and natural science.

\subsection{Data Collection}

We collected both types of data, secondary as well as primary. Secondary data is collected through various books, generals, internet, magazines and newspapers while primary data is collected through questionnaires. We collected primary data by distributing questionnaire, face to face targeting different types of population such as males, females, youngsters, elders. It also included various classes. We were intended to give more importance on face to face data collection method. Because we believed that the other methods would not have given appropriate responses. We visited selected hotels i.e. Ramada hotel and Grand Millennium Hotel in Sulaymaniyah. We used convenient sampling as our sampling technique.

\subsection{Research Design}

Research design includes types of questions, its format, contents of questionnaires and measuring instruments. The format of questions is simple and straight, a respondent has to mention his/her preference of the choices given by selecting the options already given in questionnaires. There are question which use rating scale to understand consumer preference among the in house services provided by the hotel. We selected these types of questions due to maximum out comes, quick response and easy to answer for responders. We measured the responses by using descriptive statics and also used some simple statistical tools such as correlation. 
The details of statistical test are as follows:

$\mathrm{X}$ : The importance of room service on the rating scale

Y: Type of hotel preferred by the respondents

R: Pearson correlation coefficient

$$
r=\frac{\sum(x-\bar{x})(y-\bar{y})}{\sqrt{\sum(x-\bar{x})^{2} \sum(y-\bar{y})^{2}}}
$$

We used Statistical Package for social sciences to analyze the data.

\subsection{Validity and Reliability}

We had concerned about the validity of the data. Therefore we asked questions by considering validity issue we were well aware what to ask to get the appropriate expected out comes. By considering validity issue, we did not ask direct question related to objectives instead we asked indirect questions to achieve purpose of objective. Reliability is also corned with data collection method. It means data collected will not differ even if the responders are changed or sample size. Researcher has also taken sufficient care with considering reliability issue for preparation of questions. The result should be remaining same even if there is any change of any variable.

\section{Findings}

Table 1. When or on which occasion you need to stay in a Hotel?

\begin{tabular}{|l|l|l|l|l|l|}
\hline & & Frequency & Percent & Valid Percent & Cumulative Percent \\
\hline Valid & On a Vacation & 13 & 43.3 & 43.3 & 43.3 \\
\cline { 2 - 6 } & On a business trip & 9 & 30.0 & 30.0 & 73.3 \\
\cline { 2 - 6 } & $\begin{array}{l}\text { For temporarily } \\
\text { living place }\end{array}$ & 2 & 6.7 & 6.7 & 80.0 \\
\cline { 2 - 6 } & Other options & 6 & 20.0 & 20.0 & 100.0 \\
\cline { 2 - 6 } & Total & 30 & 100.0 & 100.0 & \\
\hline
\end{tabular}


When or on which occasion you need to stay in a Hotel?

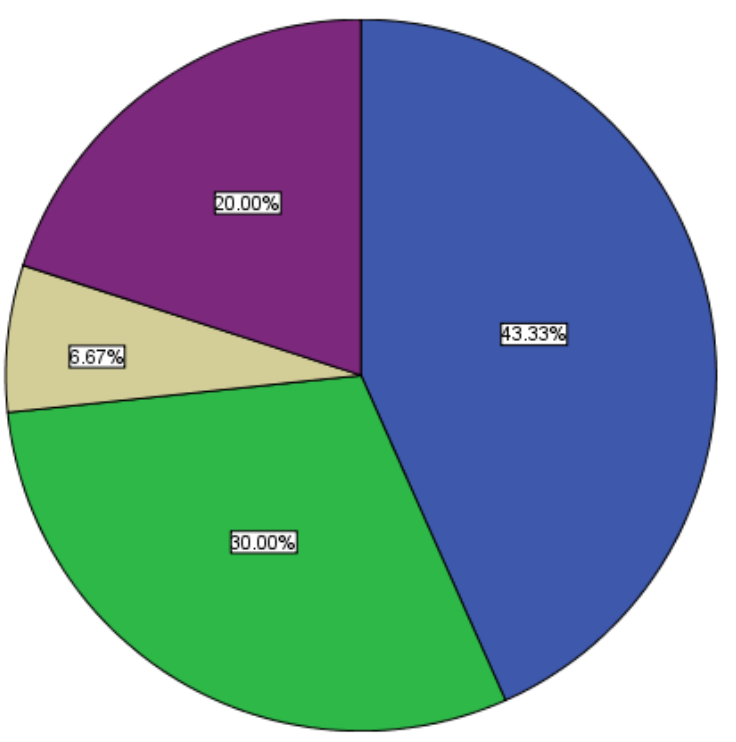

口On a Vacation
口On a business trip

For temorarly living place

other options

It can be seen that the number of respondent are mostly on a vacation when they are staying at a hotel. And have an equally distributed behavior on the other options, whether they are on a business trip, for a temporary living place and other options. On the last option we have some answers stated that they need to stay in a hotel when they are on a family visit as well.

Table 2. Which kind of hotels do you most likely stay in?

\begin{tabular}{|l|l|l|l|l|l|}
\hline & & Frequency & Percent & Valid Percent & Cumulative Percent \\
\hline Valid & Five star hotels & 21 & 70.0 & 70.0 & 70.0 \\
\cline { 2 - 6 } & Four star hotels & 5 & 16.7 & 16.7 & 86.7 \\
\cline { 2 - 6 } & Three star hotels & 4 & 13.3 & 13.3 & 100.0 \\
\cline { 2 - 6 } & Total & 30 & 100.0 & 100.0 & \\
\hline
\end{tabular}

Which kind of hotels do you most likely stay in?

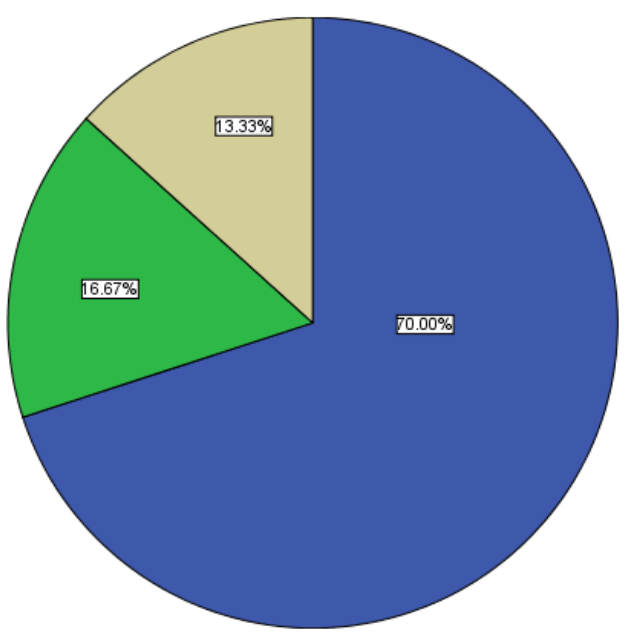

GFive star hotels
GFour star hotels

Three star hotels

From the pie chart it is clear that the majority of participants prefer to be in a five star hotel. 


\section{Macrothink}

Business and Economic Research ISSN 2162-4860 2020, Vol. 10, No. 1

Nearly a third of participants would choose a four and three star hotels. This further validates that service quality does matter and this is one of the reasons why customer prefers to stay in a five star hotel.

Table 3. Choose top 3 offers of your interest?

\begin{tabular}{|l|l|l|l|l|l|}
\hline & & Frequency & Percent & Valid Percent & Cumulative Percent \\
\hline Valid & Discounted prices & 12 & 40.0 & 40.0 & 40.0 \\
\cline { 2 - 6 } & Bring a friend for free & 10 & 33.3 & 33.3 & 73.3 \\
\cline { 2 - 6 } & $\begin{array}{l}\text { Deal for } \\
\text { introducing others }\end{array}$ & 2 & 6.7 & 6.7 & 80.0 \\
\cline { 2 - 6 } & Deal for frequent guest & 6 & 20.0 & 20.0 & 100.0 \\
\cline { 2 - 6 } & Total & 30 & 100.0 & 100.0 & \\
\hline
\end{tabular}

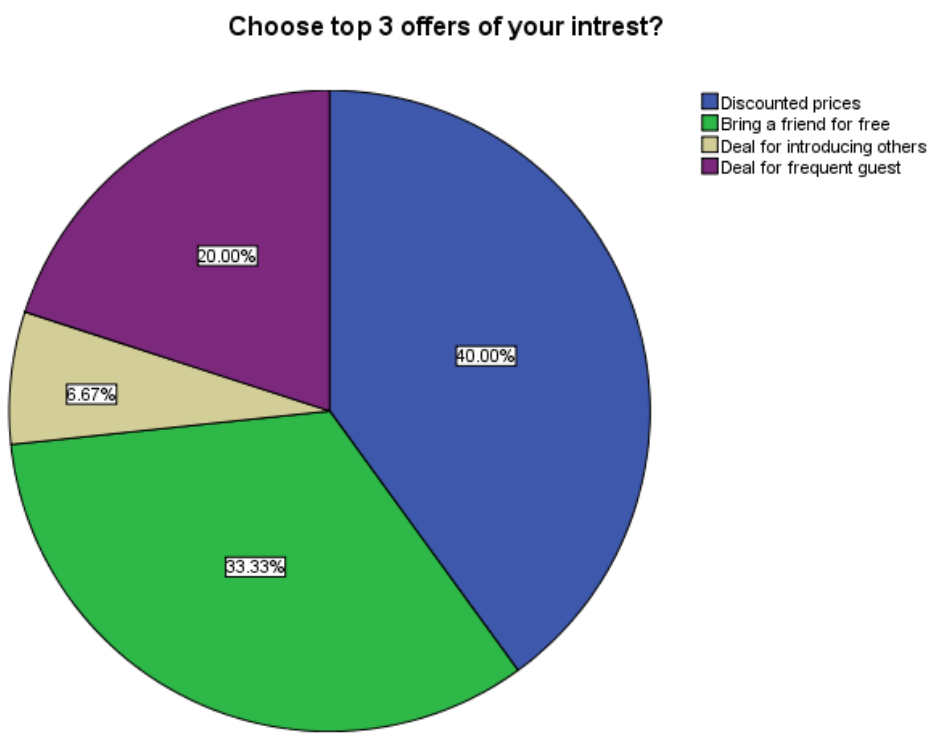

This graph shows which of the offers is in your interest. In this we have four options were the participants were able to favor in. The pie chart indicates that the widely held choose to get the offer of discounted prices, while the option of getting an offer of bringing a friend is also attractive strategy. While the minority choose of offer is getting a deal for introducing others and a deal for frequent guest.

Table 4. Importance of Room services

\begin{tabular}{|l|l|l|l|l|l|}
\hline & & Frequency & Percent & Valid Percent & Cumulative Percent \\
\hline \multirow{4}{*}{ Valid } & Very important & 13 & 43.3 & 43.3 & 43.3 \\
\cline { 2 - 6 } & Somewhat important & 11 & 36.7 & 36.7 & 80.0 \\
\cline { 2 - 6 } & Neutral & 6 & 20.0 & 20.0 & 100.0 \\
\cline { 2 - 6 } & Total & 30 & 100.0 & 100.0 & \\
\hline
\end{tabular}




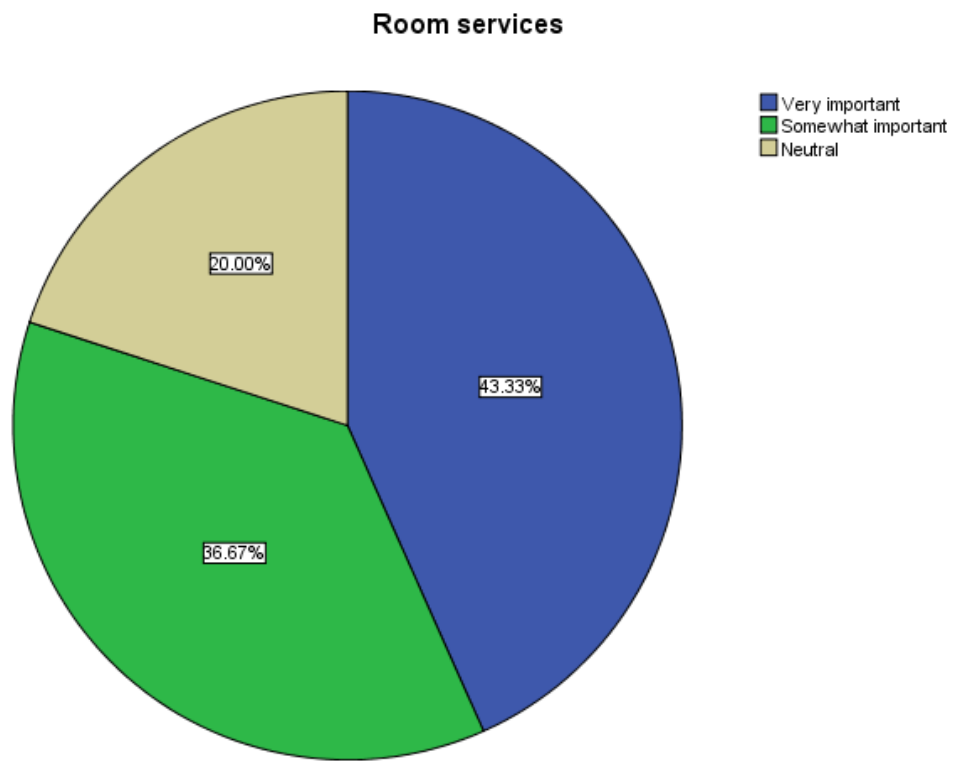

This question is related to what degree the participants consider the room service as important. As the answers clearly shows the paramount importance, we can conclude that room service should be one of the main priorities of a hotel.

Table 5. Importance of Service completion

\begin{tabular}{|l|l|l|l|l|l|}
\hline & & Frequency & Percent & Valid Percent & Cumulative Percent \\
\hline \multirow{3}{*}{ Valid } & Very important & 5 & 16.7 & 16.7 & 16.7 \\
\cline { 2 - 6 } & Somewhat important & 19 & 63.3 & 63.3 & 80.0 \\
\cline { 2 - 6 } & Neutral & 6 & 20.0 & 20.0 & 100.0 \\
\cline { 2 - 6 } & Total & 30 & 100.0 & 100.0 & \\
\hline
\end{tabular}

Service completion

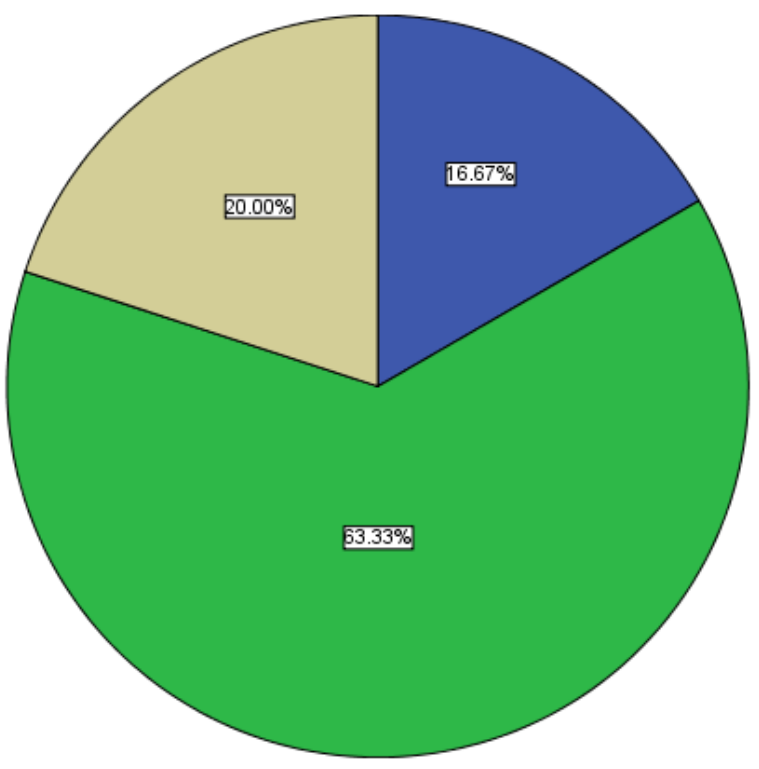

This graph shows the result of the survey in which people consider the importance of service 
completion. This shows how satisfied they were when it was completed on time. The majority of the results have indicated the service is somewhat important.

Table 6. Importance of Friendly staff

\begin{tabular}{|l|l|l|l|l|l|}
\hline & & Frequency & Percent & Valid Percent & Cumulative Percent \\
\hline \multirow{3}{*}{ Valid } & Very important & 20 & 66.7 & 66.7 & 66.7 \\
\cline { 2 - 6 } & Somewhat important & 7 & 23.3 & 23.3 & 90.0 \\
\cline { 2 - 6 } & Neutral & 3 & 10.0 & 10.0 & 100.0 \\
\cline { 2 - 6 } & Total & 30 & 100.0 & 100.0 & \\
\hline
\end{tabular}

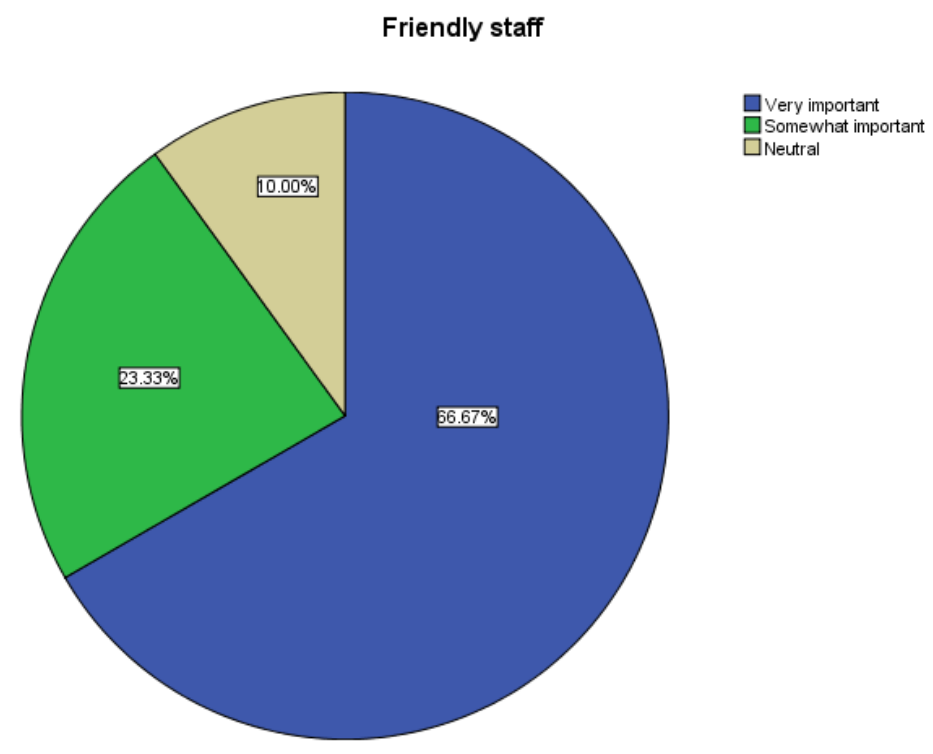

The given illustration compares the opinions on how important it is for the respondent to have a friendly staff. The pie chart demonstrates that this point is highly appreciated and is very important for the guests to have a friendly staff. With over half of the respondents answering this option. Rest of the respondent have answered this as somewhat important and neutral. To conclude the overall behavior of staff with the customer pays a key role in customer satisfaction.

Table 7. Importance of a friendly welcome on arrival

\begin{tabular}{|l|l|l|l|l|l|}
\hline & & Frequency & Percent & Valid Percent & Cumulative Percent \\
\hline \multirow{3}{*}{ Valid } & Very important & 19 & 63.3 & 63.3 & 63.3 \\
\cline { 2 - 6 } & Somewhat important & 9 & 30.0 & 30.0 & 93.3 \\
\cline { 2 - 6 } & Neutral & 2 & 6.7 & 6.7 & 100.0 \\
\cline { 2 - 6 } & Total & 30 & 100.0 & 100.0 & \\
\hline
\end{tabular}


A friendly welcome on arival

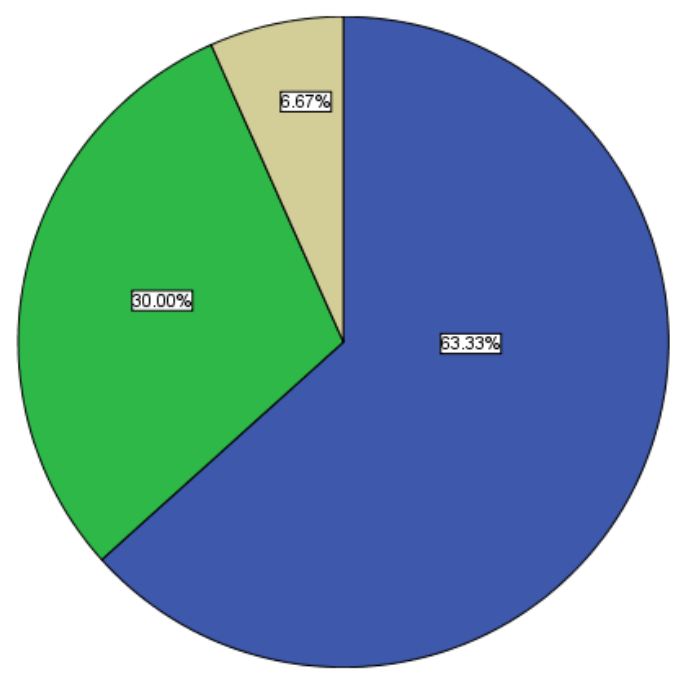

$\square$ Very important
$\square$ Somewhat important

$\square$ Neutral

A friendly welcome is a small gesture to show the guest that the hotel care about them, however by asking the participants on how important they consider they said it is very important because it gives you a good vibe.

Table 8. Importance of a quick check-in/out procedure

\begin{tabular}{|l|l|l|l|l|l|}
\hline & & Frequency & Percent & Valid Percent & Cumulative Percent \\
\hline \multirow{4}{*}{ Valid } & Very important & 21 & 70.0 & 70.0 & 70.0 \\
\cline { 2 - 6 } & Somewhat important & 4 & 13.3 & 13.3 & 83.3 \\
\cline { 2 - 6 } & Neutral & 5 & 16.7 & 16.7 & 100.0 \\
\cline { 2 - 6 } & Total & 30 & 100.0 & 100.0 & \\
\hline
\end{tabular}

A quick check-in/out procedure

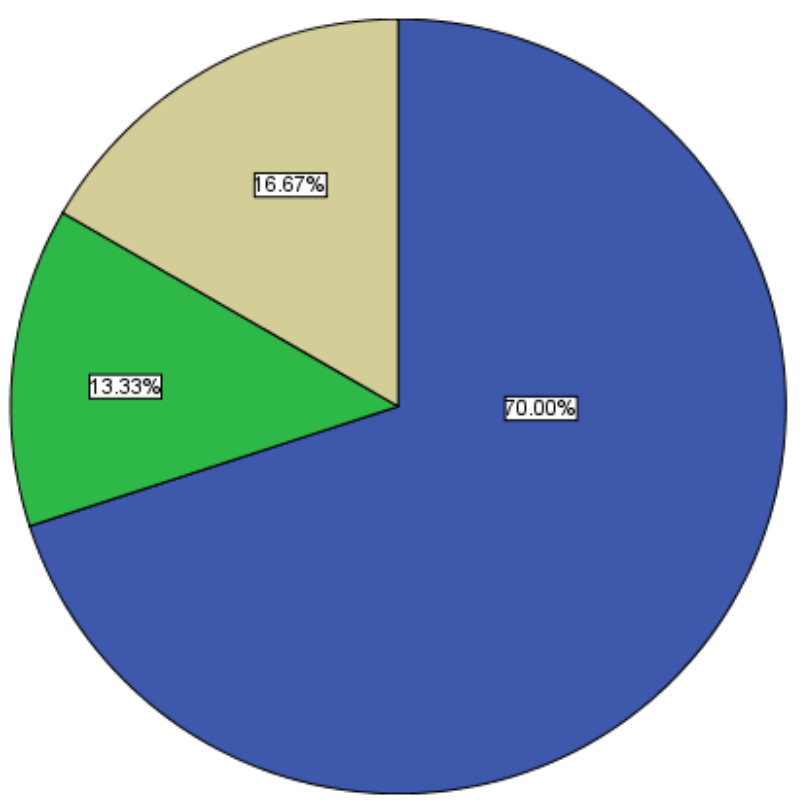

$\square$ Very important
$\square$ Somewhat important

$\square$ Neutral 


\section{Macrothink}

Business and Economic Research

ISSN 2162-4860 2020, Vol. 10, No. 1

The given pie shows how important a quick check-in/out procedures is for the respondents, out of all the respondents, 70 percent have chosen very important. This can explain the fact that time is very important for guests.

Table 9. Importance of the atmosphere in your room

\begin{tabular}{|l|l|l|l|l|l|}
\hline & & Frequency & Percent & Valid Percent & Cumulative Percent \\
\hline \multirow{3}{*}{ Valid } & Very important & 15 & 50.0 & 50.0 & 50.0 \\
\cline { 2 - 6 } & Somewhat important & 11 & 36.7 & 36.7 & 86.7 \\
\cline { 2 - 6 } & Neutral & 4 & 13.3 & 13.3 & 100.0 \\
\cline { 2 - 6 } & Total & 30 & 100.0 & 100.0 & \\
\hline
\end{tabular}

The atmonsphare in your room

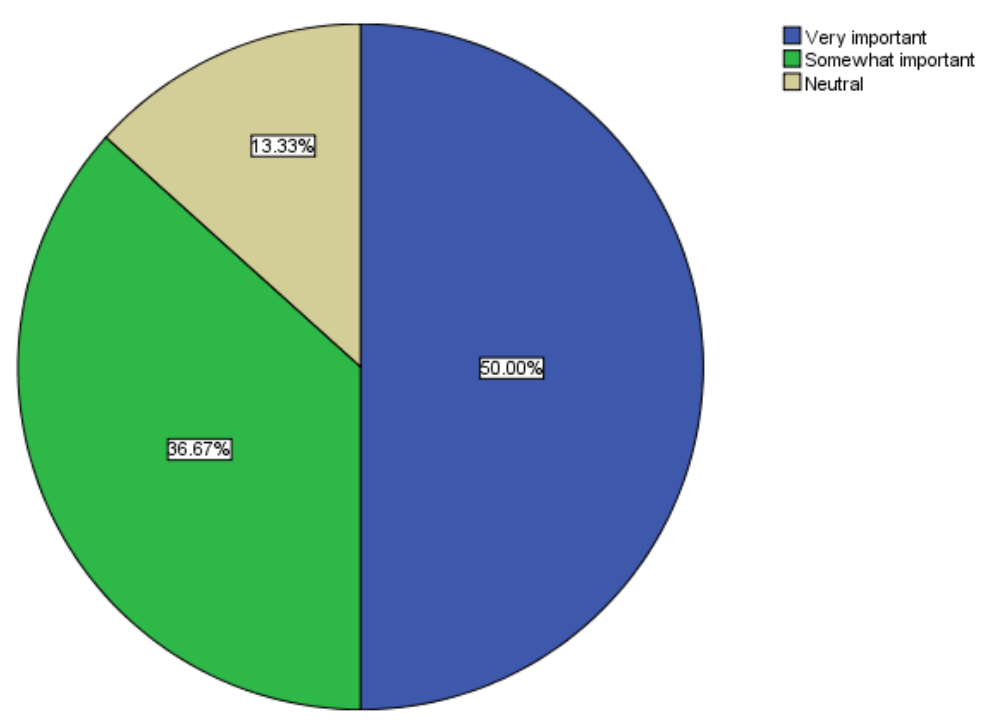

From the pie chart we can see a generally equally distributed answer on the very important, and somewhat importance, with a minority of answering as a neutral importance. Room atmosphere is important but not at the maximum degree.

Table 10. Importance of new and modern facilities of the room

\begin{tabular}{|l|l|l|l|l|l|}
\hline & & Frequency & Percent & Valid Percent & Cumulative Percent \\
\hline \multirow{3}{*}{ Valid } & Very important & 12 & 40.0 & 40.0 & 40.0 \\
\cline { 2 - 6 } & Somewhat important & 18 & 60.0 & 60.0 & 100.0 \\
\cline { 2 - 6 } & Total & 30 & 100.0 & 100.0 & \\
\hline
\end{tabular}


New and modern facilities of the room

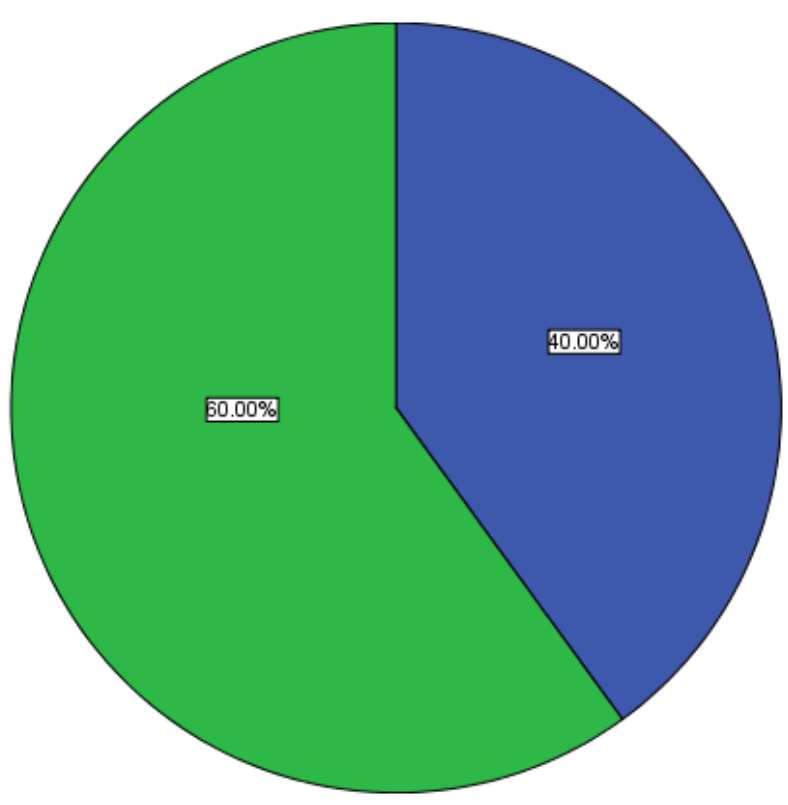

From the information shown in this pie chart, the answers indicate that having modern facilities in the rooms are very important and must be a first priority to consider if you would like to raise a quality.

Table 11. Importance of discipline and the cleanness of hotel staff

\begin{tabular}{|l|l|l|l|l|l|}
\hline & & Frequency & Percent & Valid Percent & Cumulative Percent \\
\hline \multirow{3}{*}{ Valid } & Very important & 18 & 60.0 & 60.0 & 60.0 \\
\cline { 2 - 6 } & Somewhat important & 10 & 33.3 & 33.3 & 93.3 \\
\cline { 2 - 6 } & Neutral & 2 & 6.7 & 6.7 & 100.0 \\
\cline { 2 - 6 } & Total & 30 & 100.0 & 100.0 & \\
\hline
\end{tabular}

Discipline and the cleanness of hotel staff

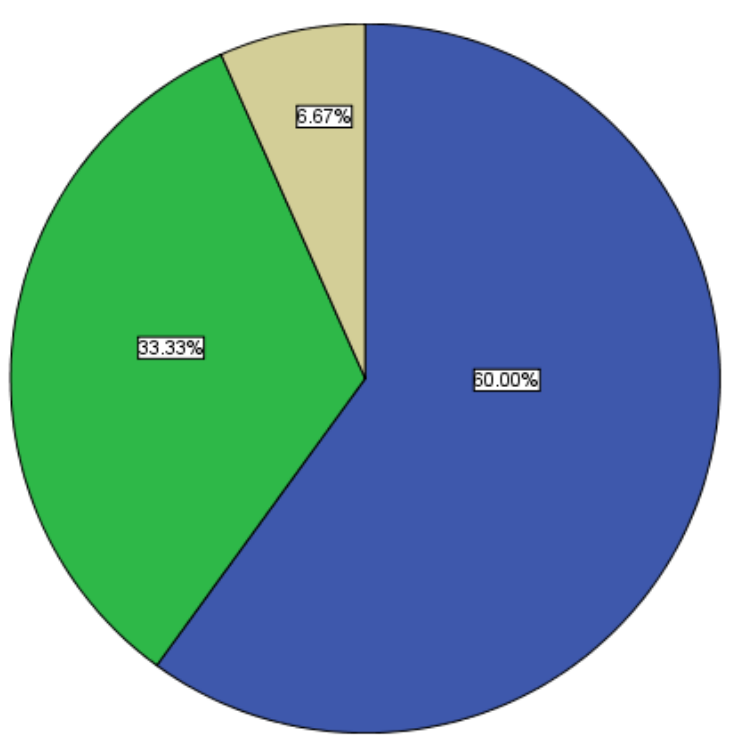




\section{Macrothink}

Business and Economic Research

ISSN 2162-4860

2020, Vol. 10, No. 1

The evidence from this pie chart shows the degree of importance of the cleanness and discipline of the staff of the hotel is very important.

Table 12. Importance of Quality of service, food and beverage in restaurant/bar

\begin{tabular}{|l|l|l|l|l|l|}
\hline & & Frequency & Percent & Valid Percent & Cumulative Percent \\
\hline Valid & Very important & 18 & 60.0 & 60.0 & 60.0 \\
\cline { 2 - 6 } & Somewhat important & 10 & 33.3 & 33.3 & 93.3 \\
\cline { 2 - 6 } & Neutral & 2 & 6.7 & 6.7 & 100.0 \\
\cline { 2 - 6 } & Total & 30 & 100.0 & 100.0 & \\
\hline
\end{tabular}

Quality of service, food and beverage in restaurant/bar
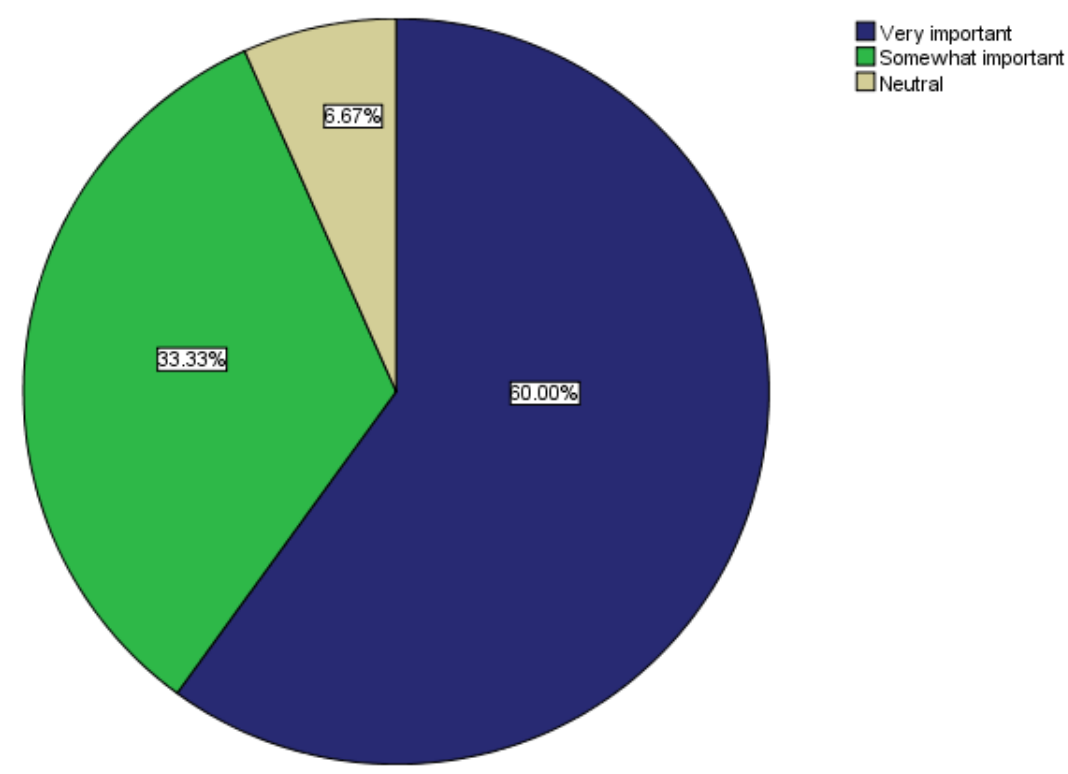

As the previous pie graph, the answers to this question are similar. People consider the service, food and beverages as a highly important. The majority wants the services of food and beverages in the hotel's restaurant should be a priority in order to raise the hotels standards.

Table 13. Which other facility in a hotel are you also interested in?

\begin{tabular}{|l|l|l|l|l|l|}
\hline & & Frequency & Percent & Valid Percent & Cumulative Percent \\
\hline Valid & Tour guide & 3 & 10.0 & 10.0 & 10.0 \\
\cline { 2 - 6 } & Resturant and bar & 7 & 23.3 & 23.3 & 33.3 \\
\cline { 2 - 6 } & Casino & 3 & 10.0 & 10.0 & 43.3 \\
\cline { 2 - 6 } & Spa/health center & 5 & 16.7 & 16.7 & 60.0 \\
\cline { 2 - 6 } & Beauty salon & 2 & 6.7 & 6.7 & 66.7 \\
\cline { 2 - 6 } & Gym & 2 & 6.7 & 6.7 & 73.3 \\
\cline { 2 - 6 } & Swimming pool & 8 & 26.7 & 26.7 & 100.0 \\
\cline { 2 - 6 } & Total & 30 & 100.0 & 100.0 & \\
\hline
\end{tabular}


Which other properties in a hotel are you also interested in? (Please check that all apply)

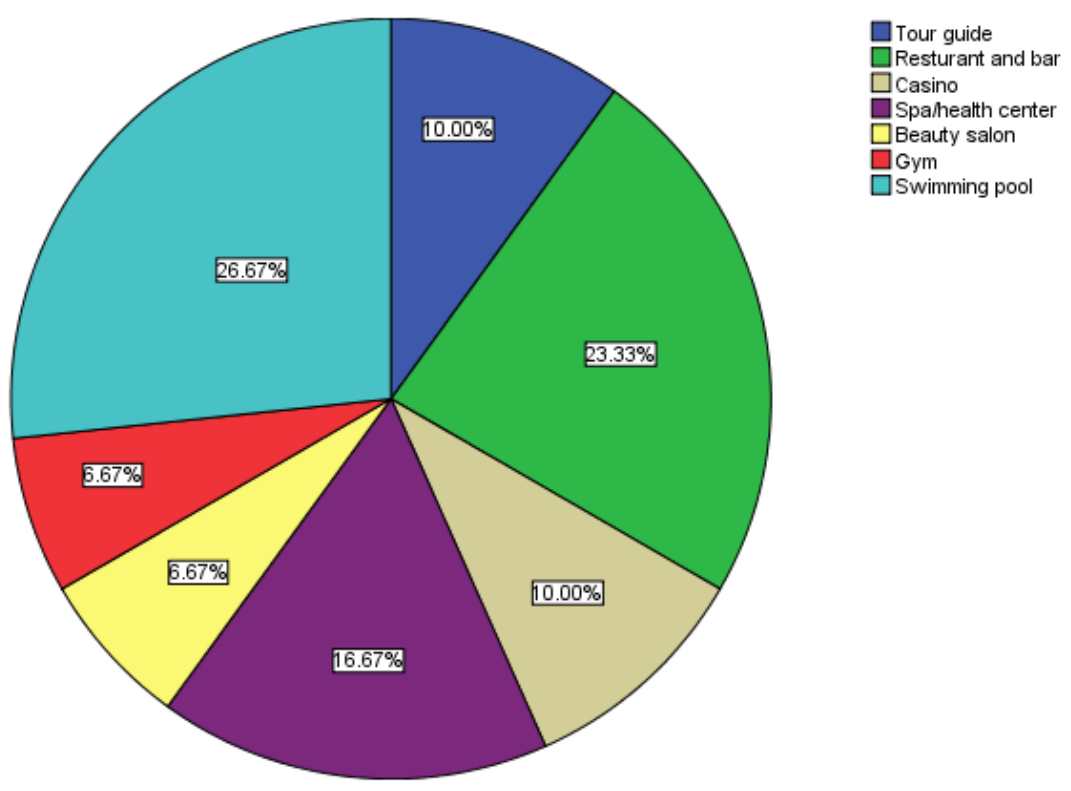

The pie chart is about what other facilities the guests would like to have, as we can observe we see that the respondents have different opinions as what they are mostly interested in. the highest vote goes to swimming pool. With the percentage of $26.67 \%$, the answer closest to the mentioned above is the restaurant and bar. This may tell us that people are interested in having these as top priority.

Table 14. Which facilities do you need in the bathroom of a hotel?

\begin{tabular}{|l|l|l|l|l|l|}
\hline & & Frequency & Percent & Valid Percent & Cumulative Percent \\
\hline Valid & $\begin{array}{l}\text { Shampoo and conditioner } \\
\text { for different types of hair }\end{array}$ & 11 & 36.7 & 36.7 & 36.7 \\
\cline { 2 - 6 } & $\begin{array}{l}\text { Toothpaste and } \\
\text { tooth brush }\end{array}$ & 7 & 23.3 & 23.3 & 60.0 \\
\cline { 2 - 6 } & Depilatory cream/wax & 3 & 10.0 & 10.0 & 70.0 \\
\cline { 2 - 6 } & Suntan cream & 1 & 3.3 & 3.3 & 73.3 \\
\cline { 2 - 6 } & Body lotion & 3 & 10.0 & 10.0 & 83.3 \\
\cline { 2 - 6 } & Comb & 2 & 6.7 & 6.7 & 90.0 \\
\cline { 2 - 6 } & Music & 2 & 6.7 & 6.7 & 96.7 \\
\cline { 2 - 6 } & Others (please specify) & 1 & 3.3 & 3.3 & 100.0 \\
\cline { 2 - 6 } & Total & 30 & 100.0 & 100.0 & \\
\hline
\end{tabular}




\section{Which facilities do you need in thebathroom of a hotel?}

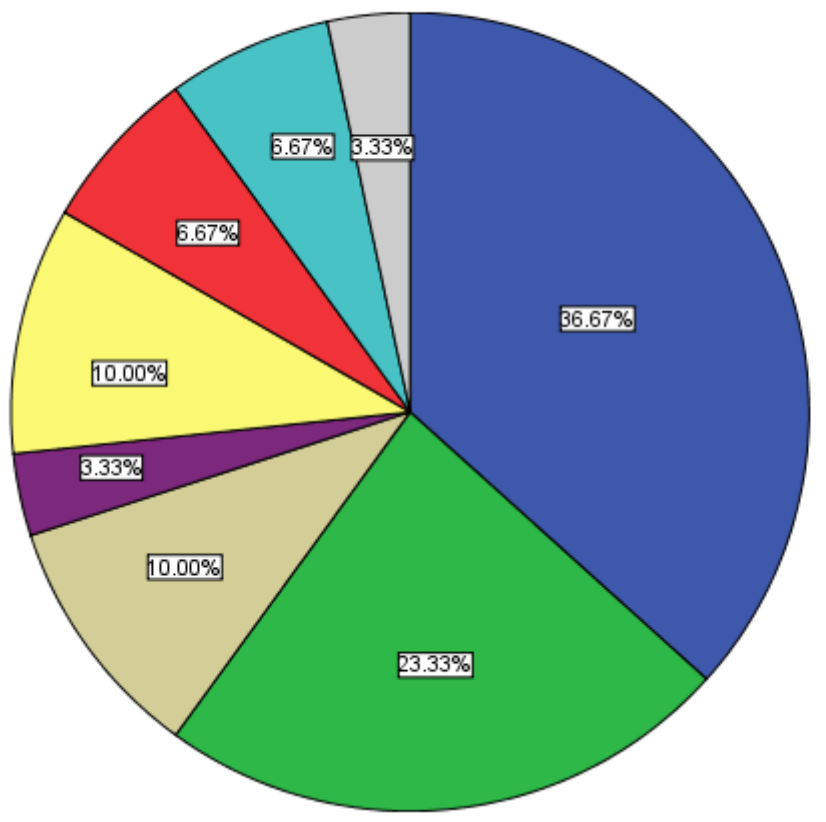

$\square$ Shampoo and conditioner for

GToothpaste and tooth brush

Depilatory cream/wax

Suntan cream

Body lotion

Music

$\square$ Others (please specify)

The bathroom of a hotel plays key role in customer satisfaction, therefore having additional facilities is highly appreciated and will raise the quality of the hotel. From the chart it is clear that customers in this area have some basic preference.

Table 15. Do you prefer a separate package for your gender?

\begin{tabular}{|l|l|l|l|l|l|}
\hline & & Frequency & Percent & Valid Percent & Cumulative Percent \\
\hline Valid & $\begin{array}{l}\text { A seperate package } \\
\text { for women }\end{array}$ & 17 & 56.7 & 56.7 & 56.7 \\
\cline { 2 - 6 } & $\begin{array}{l}\text { A seperate package } \\
\text { for men }\end{array}$ & 13 & 43.3 & 43.3 & 100.0 \\
\cline { 2 - 6 } & Total & 30 & 100.0 & 100.0 & \\
\hline
\end{tabular}

Do you prefer a seperate package for your gender?

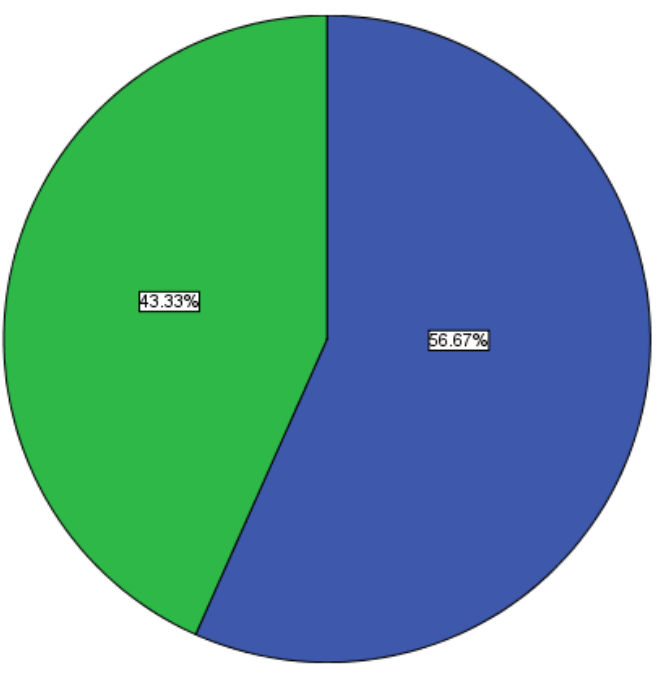

A seperate package for women 
The respondent answered, as we can see the majority of the votes has gone for "a separate package for women" this shows that women find it more important to have a customized package for themselves.

\subsection{Limitation}

- One of the obstacles that we faced was that the three hotels we chose for our questionnaires were highly strict about us distributing the surveys, this became a challenge for us.

- Another barrier was that High Crest hotel did not give us any chance to even explain to them what the questionnaires was about and why we want to distribute it, they didn't allow us to give them the surveys or not even gather information on their hotels. We used Booking.com to look at the reviews that people have submitted on High Crest hotel, in order to gather information on the hotel.

- 30 respondents are not representative enough to conclude anything, and infact our correlation coefficient shows no relation between the selected variables which is contrary to the theory, which is why we did not include the test result in this article.

\section{Conclusion}

In conclusion, most countries raise economical capital through hospital and tourism industries. Most developed countries improve the standard of living by paying attention to the growing sectors of the economy. This research mainly focuses on the quality service of the hotels, since the hotels are entering the market more and more these days it has created a huge competition between the hotels. Which leads the hotels to create the best environment for their customers and guests, quality service plays a huge role in creating a place that people would definitely come back to. The world is becoming a smaller place by globalization and this leads the tourism and hotel industry to strive to get on the top of the hotel chains, to be known around the globe and become a brand so as to attract customers. This globalization leads hotels to open chains at various locations, this way hotels can beat many competitors and be able to convince their customers that their hotels are available in many different countries which allows them to have loyal customers. hotels nowadays invest heavily in quality service to improve their service to their best, the most important reason is to make it feel like home for their guests. Customers are top priority for all hotels, particularly in high class hotels because they care about the reputation of their hotels and are trying to maintain a competitive advantage with the competitors. This research mainly studies around the hotels in the region of Kurdistan, Sulaymaniyah that is slowly transferring into a service sector and is becoming a tourist destination for the countries around the city of Sulaymaniyah. This gives the advantage for the city to engage in the service sector and the hotel industry as its growing. Therefore, focusing on quality service in this sector has a great impact on the research that has given many insights on how they operate as high class hotels. Throughout the research it was observed by the majority responses that customers give more attention to the behavior of staff, welcome on arrival, moderate bathroom facilities, room service and special packages based on customer category. 


\section{Recommendation}

Our recommendation for the hotel industry in Sulaymaniah city is for the hotels to get a better observation in the peak season. Meaning that during high season, such as holidays the domestic and International tourists demand increases and therefore the hotels must advertise their packages and special features beforehand to attract the holiday travellers. On the contrary, during the off-season the business travellers give business to the hotels and therefore special packeges and customized facilities for conference hall, business meetings, and bar and pool facilities should have special discounts for loyal customers. Tie up with online check-in e-commerce providers will make a huge difference. According to our observation of hotel's website, we think they need to make the website a little attractive and customer friendly with updated information. Infact the direction, address and unique selling proposition of the hotel is missing on the website.

\section{References}

Boyer, K., \& Verma, R. (2010). Operations and Supply Chain Management for the 21st Century. South-Western. Cengage Learning, Boston.

Brady, M., \& Robertson, C. (2001). Searching for a consensus on the antecedent role of service quality and satisfaction: An exploratory cross-national study. Journal of Business Research, 51(1), 53-60. https://doi.org/10.1016/S0148-2963(99)00041-7

Grove, S. J., \& Fisk, R. P. (1997). The impact of other customers on service experiences: a critical incident examination of getting along. Journal of Retailing, 73, 63-85.

https://doi.org/10.1016/S0022-4359(97)90015-4

Kotler, P., \& Keller, K. (2013). Marketing Management: 14th edition, Pearson.

Oliver, R. (2009). Satisfaction: A behavioral Perspective of the customer. Routledge, Taylor and Francis group.

Soininen, M. (2015). Development of a tourism destination. Lahti University of Applied Sciences, 51(18).

Wilson, A., Zeithaml, V., Bitner, M., \& Gremier, D. (2012). Services Marketing: Integrating Customer Focus across the Firm. 2th European edition: McGraw-hill.

http://documents.worldbank.org/curated/en/672671468196766598/pdf/106132-v2-main-repor t-P159972-PUBLIC-KRG-Economic-Reform-Roadmap-post-Decision-Review-05-30-16.pdf http://bot.gov.krd/about-kurdistan/tourism

2020https://data.worldbank.org/indicator/NV.SRV.TOTL.ZS

https://www.researchgate.net/publication/333324850_The_effect_of_customer_satisfaction_o n_service_quality_The_case_of_Iraqi_banks/link/5ce73166299bf14d95b52092/download http://ijecm.co.uk/wp-content/uploads/2019/06/7627.pdf

http://159.255.163.6/index.php/ukhjss/article/view/108/134 


\section{Macrothink}

Business and Economic Research ISSN 2162-4860 2020, Vol. 10, No. 1

http://documents.worldbank.org/curated/en/980021539372476570/pdf/130798-WP-P164676Iraq-EcoMonitor-Fall-2018-10-12-18-web.pdf

http://ajbasweb.com/old/ajbas/2017/April/20-28.pdf

\section{Copyright Disclaimer}

Copyright for this article is retained by the author(s), with first publication rights granted to the journal.

This is an open-access article distributed under the terms and conditions of the Creative Commons Attribution license (http://creativecommons.org/licenses/by/4.0/). 